\title{
Regulation of the development of defense reactions on the part of plants with the participation of rhizobia signaling molecules as the basis for the development of legume-rhizobial symbiosis

\author{
Kirienko A.N., Dolgikh E.A.
}

All-Russia Research Institute for Agricultural Microbiology (ARRIAM), Saint Petersburg, Russia

E-mail: kirienkoann@yandex.ru

\begin{abstract}
Key message. The role of the LysM-containing receptor-like kinase K1 of pea in the development of protective reactions and vesicular transport during the symbiosis development with rhizobial bacteria is shown
\end{abstract}

Keywords: legume-rhizobial symbiosis, LysM-RLK, defense reactions

Most legumes are able to establish a symbiotic relationship with rhizobial bacteria. As a result of this interaction, nitrogen fixing organs - nodules — are formed on the roots of the plants. In most legumes, the penetration of rhizobia into the root tissues and the settlement of the forming nodule occurs through special structures - infection threads. In this case, unlike the interaction with pathogenic microorganisms, legumes do not develop defense reactions in response to the rhizobia penetration. Previously, we described the role of LysM-containing receptor-like kinase of pea K1, which is necessary for recognizing the signal molecules of rhizobia Nod factors and regulating the development of symbiosis. It was found that K1 can control early symbiotic reactions, the promotion of infection threads in root tissues, and the exit of bacteria from them. Due to the fact that the penetration of rhizobia into root tissues is directly related to the control of the development of defense reactions on the part of plants, we have studied the role of $\mathrm{K} 1$ in the regulation of these processes. The mutant line $k 1-2$, which is characterized by blocking the exit of bacteria from infection threads, was used in the work. Histochemical analysis of the roots of plants of this line showed that callose deposition occurs around the possible exit sites of bacteria, which is a typical reaction of the plant to the penetration of the pathogen. It is known that both during the development of symbiosis and pathogenesis in plants, changes occur in the vesicular transport system. When analyzing transgenic pea roots with overexpression of the $K 1$ gene under the CaMV $35 \mathrm{~S}$ promoter, targets of the receptor action were identified, including both defense reaction regulators and vesicular transport components. The role of the K1 receptor and Nod factors signaling molecules in regulating the development of defense reactions when rhizobia enter plant tissues, as well as in controlling vesicular transport during symbiosis, is discussed.

This work was supported by a grant of the Russian Science Foundation 16-16-10043.

\section{Регуляция развития защитных реакций со стороны растений с участием сигнальных молекул ризобий как основа для развития бобово-ризобиального симбиоза}

Кириенко А.Н., Долгих Е.А.

ФГБНУ Всероссийский научно-исследовательский институт сельскохозяйственной микробиологии, СанктПетербург, Россия

\begin{abstract}
Аннотация. Показана роль LysM-содержащей рецептор-подобной киназы К1 гороха в контроле развития защитных реакция и везикулярного транспорта в ходе развития симбиоза с ризобиальными бактериями
\end{abstract}

Ключевые слова: бобово-ризобиальный симбиоз, LysM-PПК, защитные реакции

Большинство бобовых растений способны устанавливать симбиотические отношения с ризобиальными бактериями. В результате такого взаимодействия на корнях растения формируются органы азотфиксации - клубеньки. Наиболее распространенным способом проникновения ризобий в ткани корня и заселения формирующегося клубенька является развитие специальных структур - инфекционных нитей. При этом, в отличие от взаимодействия с патогенными микроорганизмами, у бобовых подавляются защитные реакции в ответ на проникновение ризобий. Ранее нами была описана роль LysM-содержащей рецептор-подобной киназы K1 гороха, необходимой для узнавания сигнальных молекул ризобий Nod-факторов и регуляции развития симбиоза. Установлено, что К1 может контролировать ранние симбиотические реакции, продвижение инфекционной нити в тканях корня и выход бактерий из инфекционной нити. В связи с тем, что проникновение ризобий в ткани корня непосредственно связано с контролем развития защитных реакций со стороны растений, нами была изучена роль К1 в регуляции этих процессов. В работе была использована мутантная линия кl-2, которая характеризуется блокированием выхода бактерий из инфекционных нитей. Гистохимический анализ корней растений данной линии показал, что вокруг возможных мест выхода бактерий происходит отложение каллозы, что является типичной реакцией растения на проникновение патогена. Известно, что, как при развитии симбиоза, так и при патогенезе у растений происходят изменения в системе везикулярного транспорта. При анализе трансгенных корней гороха со сверхэкспрессией гена $K 1$ под промотором CaMV $35 \mathrm{~S}$ были выявлены мишени действия рецептора, в числе которых оказались, как регуляторы защитных реакций, так и компоненты везикулярного транспорта. Обсуждается роль рецептора К1 и сигнальных молекул Nod-факторов в регуляции развития защитных реакций при проникновении ризобий в ткани растения, а также в контроле везикулярного транспорта при симбиозе.

Работа поддержана грантом РНФ 16-16-10043. 